\title{
Youth Unemployment, Empowerment And Self Reliance In Nigeria: A Panacea For Self Employment
}

\author{
Dr. Bulus Kwopnan \\ Department of Political Science, Faculty of Social Sciences, University of Jos \\ Gubak Happy Daniel \\ Department of Political Science, Faculty of Social Sciences, University of Jos
}

Gubam, Dimas Solomon

Department of Archaeology and Museum Studies, Federal University Lokoja - Nigeria

DOI: 10.29322/IJSRP.10.12.2020.p10816

http://dx.doi.org/10.29322/IJSRP.10.12.2020.p10816

\begin{abstract}
There is high level of youth unemployment in Nigeria with many negative consequences or its attendant challenges such as security challenges or insecurity problem like kidnapping, armed robbery, violence, conflicts, armed banditry, insurgency, militancy and other socio-economic challenges like prostitution, drugs among many others. These myriad challenges have long retarded or inhibited the development of the Nigerian economy. As such, this paper examines the need for youth empowerment and self-reliance in order to propel self-employment among the youths in Nigeria. Findings from the paper reveal that there is high level or rate of youth unemployment in Nigeria couple with the limited number of job opportunities provided by the government so the only way out of such situation for the youth is empowerment and self-reliance so as to be self-employed. Conclusions were drawn and recommendations made. The paper therefore recommends among others that (i) Entrepreneurship should be taught as an activity (practical) and not just as an academic field or Entrepreneurship studies should be largely practical based to enable students acquire adequate skills and knowledge needed for self-employment, (ii) Appropriate conducive environment such as quality infrastructural facilities and start-up capacity should be provided to the youth by the government. In other words, Government should provide basic infrastructures such as regular power, good roads, communication etc for entrepreneurship to boost the Nigerian economy. The paper adopts qualitative method of data analysis, drawing from secondary sources.
\end{abstract}

Key Words: Youth, Youth Unemployment, Self-Reliance, Youth Empowerment, Entrepreneurship

\section{INTRODUCTION}

Unemployment is becoming a vicious disease in Nigeria. It has been estimated that over million Nigerians are jobless and this justify that Youth unemployment has been a decimal issue in Nigeria and has provoked a lot of researches. The rate of youth unemployment in the Nigeria recently has grown in geometrical progression. Indeed, problem of poverty and unemployment has for a long time been a cause of concern to the government. Youths in Nigeria suffer high unemployment due to lack of opportunities, physical and psychological challenges resulting from poverty. Some youths respond to these challenges by engaging in criminal or violent behaviour while others suffer from despair or depression.

Unemployment creates a wide range of social ills and young people are particularly susceptible to its damaging effects. Nigeria, like many other developing countries of the world is faced with a myriad of challenges such as unemployment and poverty with their attendant consequences such as low income, youth restiveness, social insecurity, kidnapping, frustration, idleness and drug addiction etc. In Nigeria, year by year, the number of unemployed graduates keep increasing as more graduates produced by the various higher institutions are made to join the long queue of other unemployed who have earlier graduated from school. Unemployment produces an unsettled labour force, and in urban areas, it may lead to overcrowding and all forms of crimes such as drug addiction, kidnapping, youth restiveness, armed robbery among many other crimes.

This publication is licensed under Creative Commons Attribution CC BY. 
Successive governments in Nigeria have at one time or the other created many intervention schemes to stem out poverty, unemployment and empower the youths and women in the country. In other words, to address the problems or challenges of youth unemployment and making the youth self-employed and self-reliant, the Nigerian government both at the federal and state levels have in the past and the present initiated and implemented several youth empowerment programmes tailored towards addressing the youth unemployment situation in Nigeria. In other words, the Federal Government of Nigeria in an effort to fight unemployment and create jobs for its teeming youths has at various times designed policies, programmes and established agencies such as: Family Economic Advancement Programme (FEAP), Nigerian Agricultural Bank (NAB) incorporated in 1973, renamed in 1987 to Nigerian Agricultural and Cooperative Bank (NACB and merged in 2000 the People's Bank of Nigeria (PBN) and took over the risk assets of Family Economic Advancement Programme (FEAP) to become Nigerian Agricultural Cooperative and Rural Development Bank Limited, (NACRDB) and was shortened to Bank of Agriculture (BOA). Agricultural programmes such as Youth Employment in Agriculture Programme (YEAP) aimed at reducing poverty and vulnerability, Directorate of Food, Road and Rural Infrastructure (DFRRI), Poverty Alleviation Programme (PAP), National Poverty Eradication Programme (NAPEP), National Directorate of Employment (NDE), Subsidy Reinvestment and Empowerment Programme (SURE-P), Economic Empowerment and Development strategy (NEEDS), N-Power, Youth Enterprise with Innovation in Nigeria (YouWin), Youth Empowerment and Development Initiative (YEDI), Niger-Delta Development Commission's (NDDC), North East Development Commission (NEDC), National Accelerated Food Production Programme (NAFPP), National Social Investment Programme (NSIP), University Entrepreneurship Development Programme (UNEDEP) to promote self-employment among the youth, right from higher institutions of learning among others.

The federal government of Nigeria in 2004 launched another poverty alleviation scheme at all three tiers of government packaged as National Economic Empowerment Development Strategy (NEEDS), the State Economic Empowerment Development Strategy (SEEDS) and Local Economic Empowerment Development Strategy (LEEDS), holistically, operated at all three levels respectively with the aim of eradicating poverty in Nigeria. Despite all the above attempts to alleviate poverty, it is still a mirage, and as a result, the international community felt it needs to act fast and the United Nations (UN) in 2005 launched the Millennium Development Goals (MDGs) as part of effort to accelerate the attainment of MDG's ahead of the 2015 targeted date . However, the programme could not achieve most of the set goals as most African countries could not meet the said target. Given the above challenges, the Sustainable Development Goals (SDGs) came into being aimed at ending poverty, protect the planet and ensure prosperity for all. Each goal has specific target to be achieved over the next 15 years.

These programmes are aimed at empowering the people particularly the youths and addressing various manifestations of unemployment and poverty. Meanwhile, under the present economic hardship that is currently being experienced in Nigeria, there are fears that the present programme (SDGs) might also go in the way of its predecessor that is, MDGs.

Besides, as the global economy slows down with signs that it is heading towards recession, there are chances that many more nations will face socio-economic crises that would require urgent attention. This means that without rapid economic growth to sustain the nascent democratic gains, youth empowerment, poverty and unemployment situations will be grimmer as more youths will become less empowered, unemployed with varying consequences for national security. Hence, under the condition of high level of unemployment, there is urgent need to orientate the youths by inculcating in them self-empowerment, self-reliance and entrepreneurship. Human resources development and management could be an effective tool for youth empowerment, poverty reduction and self-reliance. 
Despite the initiation of this several programmes to address youth unemployment and create employment opportunities and reduce poverty for the youths by the government, they have not maximally achieved desired results (some relevant results have been achieved). However, poor funding as well as the irresponsible and corrupt implementation of these programmes have prevented government from achieving the noble objectives for which the programmes were instituted. Also, poor budgetary allocations, management and governance problems have afflicted most of the programmes, resulting in facilities not being completed, broken down, abandoned or ill-equipped. Again, lack of accountability and transparency made the programmes serve as conduit pipes for draining national resources. Their failure is also due to poor implementation, corruption of government officials and public servants, poor targeting mechanism and failure to focus directly on the poor.

Also, the scenario painted above arises because majority of these youths lack entrepreneurial skills to be self-employed.

\section{CONCEPTUAL CLARIFICATION OR DEFINITIONS OF KEY CONCEPTS}

After a careful study of various literatures on the subject matter, the study generally derived some of the various definitions of the key concepts as follows:

Youth: United Nation General Assembly defined youth as between the ages of 15-24. From the Nigerian context, the youths are segment of the population in a society within the age bracket of $18-35$ years. Usually, they tend to be active, vibrant, daring with lots of useful energy if put to positive use. The youths have contributed immensely to the development of the country from pre-colonial, independent and post independent or post-colonial era. Notwithstanding their positive contribution to the country, they constitute the critical and volatile segment of the society. The UNDP further emphasized on young women and men ages 15-24 and extend the inclusion of young men and women within the age bracket of 25-30 and even beyond age 35 based on contextual realities, regional and national youth policy directives.

Unemployment: Unemployment is situation in which people who are willing to work at the prevailing wage rate are unable to find jobs. It can also mean a state of worklessness experienced by persons who are members of the labour force, who perceived themselves and are perceived by others as capable of working. Unemployment from the perspective of the British Department of Employment, affirms that unemployed is a school-lever who is not in paid employment but who is available for working. In the view of the United Nations, unemployment consists of all persons who during the reference period, were not working but who were seeking work for pay or profit, including those who never worked before. It also indicates numbers of the economically active population who are without work but available for and seeking work, including people who have lost their jobs and those who have voluntarily left work. It can also be seen as asituation where people who are willing and capable of working are unable to find suitable paid employment. It is one of the macro-economic problems which every responsible government is expected to monitor and regulate. The higher the unemployment rate in an economy the higher would be the poverty level and associated welfare challenges.

Self-Reliance: Generally, it is the ability to think and act without the help or influence of others, the ability to decide what you should be or do. Self-reliance encourages the need for people to improve their living conditions using home initiatives and resources at their disposal. It is also seen as development that relies on "internal" resources as opposed to development that relies heavily on "external" resources. Self-reliance is synonymous with self-sufficiency. It means doing things for ourselves rather than having things done for us. Self-reliance is the personal initiative in the ability and effort to identify, harness and manage effectively and efficiently the personal and collective resources, human or natural in the immediate surroundings in order to uplift one's or a people's quality of life, standard of living and condition of existence. It also refers to the sole dependence of individual capabilities to improve life and the 
ability of an individual to rely on him/herself in order to accomplish a specific task and progress in it. The idea of self-reliance lays heavily on youth empowerment by training of mind and body of the youth for proper integration in to the society and for positive development.

Youth Empowerment: The process of continuous improvement of the youth development, structures, institutions and programmes in order to create a social condition, ensure the rights of the youth are advanced and protected, their welfare enhanced, and their effective functioning and self-actualization ensured. Youth development is a sine-quo-non for youth empowerment.

Entrepreneurship: Can be seen as the ability to identify and evaluate business opportunities, gather the necessary resources, initiate appropriate actions to ensure success and implement actions to take advantage of the opportunities for rewarding outcomes. Entrepreneurship in a country is an engine for job creation and innovation. It can also be view as the ability to perceive and undertake business opportunities, taking advantage of scares resources utilization. Entrepreneurship is also the process of creating something new with value by devoting the necessary time and effect assuming the accompanying finance psychic and social risk and reserving the resulting rewards of monetary and personal satisfaction and independence. Entrepreneurship education is a form of education that seeks to provide knowledge, skills, attitude and motivation to students for entrepreneurial success in any setting. It equips people with the ability to seek investment opportunities.

\section{CAUSES OF YOUTH UNEMPLOYMENT IN NIGERIA}

Some of the main causes of youth unemployment in Nigeria are as follows:

1. Rural Urban Migration: Rural-urban migration is usually explained in terms of push-pull factors. The push factors include the pressure resulting from man-land ratio in the rural areas and the existence of serious underemployment arising from the seasonal cycle of climate. Lack of infrastructural facilities, which makes the rural life unattractive. Youths move to urban areas with the probability of securing lucrative employment in the industries. In addition to this, there is the concentration of social amenities in the urban centers. This meant that the rural areas are neglected in the allocation of social and economic opportunities.

2. Rapid Population Growth. Nigeria is the most populous nation in Africa. The high population growth rate has resulted in the rapid growth of the labour force, which is far outstripping the supply of jobs. The fast growth of population on Nigeria's unemployment problem is multifaceted. It affects the supply side through a high and rapid increase in the labour force relative to the absorptive capacity of the economy.

3. The Outdated School Curricula and Lack of Employable Skills. Some scholars and commentators have argued that as far as the formal sector is concerned, the average Nigeria graduate is not employable and, therefore, does not possess the skills needed by the employers of labour for a formal employment. After all, employers do not need people to pay or spend their money on but people that will help their organization grow and make more profit as the primary goal of every enterprise is to make profit. Mostly, this is attributed to the education system in Nigeria, with its liberal bias. The course contents of most tertiary education in Nigeria lack entrepreneurial contents that would have enabled graduates to become job creators rather than job seekers.

4. The Rapid Expansion of the Educational System which directly leads to increase in the supply of educated manpower above the corresponding demand for them. With the creation of six new universities in the countries by the President Goodluck Administration more youths graduate without jobs. This contributes to the problem of the youth unemployment in Nigeria. Presently, with many universities in Nigeria (both federal, state, and private) and the increasing demand for higher education there has been the problem of 
suitable employment for the varieties of graduates who are turned out by these higher institutions every year. Ordinarily, this should not have been a problem, but the reality is that the Nigerian economy is too weak to absorb this large number of graduates.

5. Lack of Vibrant Manufacturing Sector: Also, there is no vibrant manufacturing sector which has the capacity to absorb unemployed youths in Nigeria. However, Nigeria is a country with numerous business and investment potentials due to the abundant, vibrant and dynamic human and natural resources it possesses. Even though the country has such potentials, it continues to experience its share of social, economic and political upheavals which have often stunted and retarded its growth and development into the regional economic power that it strives to attain. There is high rate of violent crimes in Nigeria. The fact is that Nigeria is becoming hostile to investment due especially to lack of steady and sustainable power supply energy crisis in spite of the various attempts are reviving this sector lading to firms depending on generators for their operation whose cost of buying, fueling and maintenance are high, thereby increasing the cost of operation in Nigeria. Also, high and multiple levies and taxations being paid by these companies, energy crises have combined to make the cost of doing business in Nigeria to be very high. When the industries and factories closed shops or relocated to a friendlier economic environment, workers were laid off and prospects of recruiting new ones were dashed. All these exacerbated the crisis of youth unemployment in the labor market.

6. Corruption: Corruption has permeated the entire social structure of the country and has robbed the country of developing a vibrant economic base. Funds meant for development projects have been misappropriated, diverted, or embezzled and stashed away in foreign banks, while some incompetent and corrupt bureaucrats and administrators in the public enterprises and parastatals have liquidated these organizations. The collaboration of the political elites, local and foreign contractors in the inflation of contract fees have robbed the country of the chances of using billions of dollars estimated revenue from the oil sale to develop a vibrant economy that would have created jobs for the youths in various sectors of the economy. The ruling (political) class failed because they replaced the vision, policy, and strategy, which should be the thrust of every leadership with transactions (contract award and other mundane money related activities), as each successive government took turns to prey on the nation's wealth, by using public power, resources, good will, utilities, instrument of abuse, and personal gains. Thus, crippling the economy and engendering and exacerbating unemployment which creates abject poverty, hunger and frustration; killing the zeal and means for entrepreneurship development in the Nigerian youths.

7. Lack of Steady and Sustainable Power Supply: Lack of Steady and Sustainable Power Supply or epileptic or intermittent power supply normally affects the productivity of infant or local industries there by reducing the rate of income in the country and forcing some of them out of business.

\section{COMPONENTS OF YOUTH DEVELOPMENT AND EMPOWERMENT}

(1) Youth Employment: Employment opportunities should be provided by the ruling elites to gainfully employ and empower the youths who incidentally are the future leaders. Where there is insufficient paid employment, the ruling petit-bourgeoisies should create enabling environment to sustain entrepreneurship and operation of small-scale ventures.

(2) Youth Education and Training: Education is power, it is one of the major indicators of measuring development. Therefore, youth training programs including vocational training through talent/skill assessment inventory.

(3) Entrepreneurship skill acquisition should be inculcated in the educational curriculum to cut across all specter of educational system in order to position the youths in act of management, analysis and effective operation of business. 
(4) Research, evaluation and publication of such researches, especially those that relate to skill acquisition would foster youth development.

(5) Liaising with state youth departments and international organizations

(6) National youth award scheme.

(7) International youth exchange programme.

(8) Youth holiday programme.

(9) National youth camps.

(10) Coordinating activities of national voluntary youth organizations.

(11) Youth mobilization - Political and social mobilization agencies should be set up and their services should be complemented by non-governmental organizations. They will handle youth mobilization, business and political education. Funds should be made available for effective running of such outfits.

(12) Establishment of coordinating bodies to monitor and evaluate government programmes and policies as they relate to the youth.

\section{NEED OR REASON FOR ENTREPRENEURSHIP DEVELOPMENT IN NIGERIA}

Economic and social realities of today have made it imperative for orientation and re-orientation of people towards entrepreneurship and private sector-based economy. The increasing focus on entrepreneurship development in the country has become obvious for a number of reasons:

(1). Government Economic Reforms: The Nigerian economic environment has been witnessing extensive fundamental reforms such as austerity measure, privatization, commercialization, structural adjustment programme, the new industrial policy in Nigeria and deregulation measures. A major feature of these reforms is the steady but gradual withdrawal of government from direct involvement in production and distribution of goods and services.

(2). The Failure of past industrial policies, which were anchored on large capital-intensive projects, to generate self-sustained growth, create employment, resulting in change in large scale industrial promotion strategy and import substitution strategy.

(3). The increasing population of school leavers and graduate of various higher institutions in the country who roam the streets searching for white collar jobs which are very scarce. The high rate of graduate unemployment in the country is gradually leading to underemployment for some people and various forms of exploitation for others.

(4) The influence of globalization and advancement in information technology on jobs and employment could be said to be the most extensive and pervasive globally. Advancement in technology has rendered many organizational systems obsolete, caused the need for restructuring and re-organization with consequential loss of old jobs. In a similar vein, such changes have opened up avalanche of opportunities in all areas where technology can apply.

(5) Industrial downsizing as a result of recently experienced national and global economic recession, resulting in loss of jobs and low rate of new job creation. 
(6). The federal government has also realized the significant importance of small and medium scale businesses in its current Poverty Eradication Programme. This could be seen from the entrepreneurship development aspect of small and medium enterprises (SMEs) that bear direct relevance to the empowerment of the population for sustainable development.

(7). The success stories of such countries like the United States of America (USA), India, Indonesia and Malaysia etc, where small business development has accelerated their economic and industrial transformation.

(8). Furthermore, the emerging social vision which supports women employment and economic empowerment to help reduce adverse economic pressures on the family has really created a need for entrepreneurship in our country.

\section{OBJECTIVES OF GOVERNMENT'S ENTREPRENUERSHIP EDUCATION}

The continuous increase in the rate of youth unemployment in the country may indicate lack of entrepreneurship rather than lack of opportunities. In 2006, the presidency directed all tertiary institutions to include Entrepreneurship Education (EED) as a compulsory course for all students with effect from the 2007/2008 academic session. The essence is to inculcate in the trainees the ability to identify and solve problems using creative and critical thinking, thus making them self-reliant. Thus, Entrepreneurship education (EED) as structured by government is intended to achieve the following objectives:

(1). To offer functional education to the youths that will enable them to be self-employed and self-reliant.

(2.) To provide the youths with adequate training that will enable them to be creative and innovative in identifying viable business opportunities.

(3). To reduce the high rate of poverty among Nigerians.

(4). To reduce rural urban migration.

(5). To provide the young graduates with enough training and support that will enable them establish a career in small and medium sized businesses.

(6). To inculcate the spirit of perseverance in youths and adults which will enable them to persist in nay business venture they embark on.

(7). To create a smooth transition from traditional to a modern industrial economy.

(8). To create employment.

(9). To serve as a catalyst for economic growth and development.

Entrepreneurship education is designed to enable students acquire skills, abilities and capabilities for self-employment rather than paid employment. It enables trainees or students to acquire basic skills, attitudes and ideas which will help them start new businesses. Generally, the main focus of entrepreneurship education in Nigeria is to empower our youths irrespective of area of specialization, with skills that will enable them to engage income generating ventures where they are unable to secure white collar jobs on graduation.

\section{CHALLENGES OF ENTREPRENEURSHIP IN EMPLOYMENT CREATION IN NIGERIA}


Challenges of entrepreneurship development could either be economic resources or human resources. Economic resources are made up of labour, land capital and entrepreneurial abilities, which when combined produce a great output. The key roles of entrepreneurship include mobilization of domestic savings for investment, significant contribution to Gross Domestic Product (GDP) and Gross National Income (GNI), harnessing of local raw materials, employment creation, poverty reduction and alleviation, enhancement in standard of living, increase in per capita income, skills acquisition, advancement in technology and expert growth and diversification. Irrespective of the benefits associated with entrepreneurship, there are lots of barriers that have prevented youths from fully realizing their potentials and assuming responsibilities in the society.

1. Absence of Infrastructural Facilities: Basic infrastructural facilities aid the development of the mind and body and assist productivity in any environment. These facilities include good roads, good water supply, constant power supply or electricity, access to information and communication technology and other implements of trade. Where these are lacking in a country, the growth of the economy will be negatively affected. These basic work tools as well as the enabling environment is lacking in Nigeria. All these have made entrepreneurial activities cost intensive, unprofitable and uninteresting thereby dissuading and denying the youths from assuming entrepreneurial leadership positions.

2. Inadequate Working Capital. The availability of capital is central to the establishment and continued existence of any enterprise irrespective of the size, focus and objective. For an entrepreneur in Nigeria to start a business, he /she must have adequate funds. In a situation where the working capital is inadequate or unavailable, it becomes a problem. This is one of the main, if not the main challenge that young people encounter when opening a business. Banks are reluctant to give out loans to intending entrepreneurs especially when they are young people. The procedures for accessing such credits are often rigorous and dependent on the provision of collaterals which the potential entrepreneur may not possess. Therefore, intending entrepreneurs often fall back on their personal savings or on loans from family members and friends.

3. Low Standard of Education: The world today is a global village and since an intending entrepreneur must be conversant and in tune with events around and about him, education becomes a critical factor in preparing and empowering the entrepreneur with the qualities required of him. Unfortunately, the role of education in forming young people to become change agents seems to have been ignored. Year after year, the quality of education in the Nigerian institutions has gradually been on the decline, due to strikes and unqualified teachers. While those who stay in the system is as a result of the unavailability of alternative jobs. Lack of good education policy has been a major bane of education in Nigeria. The government does not give maximum priority to education. The schools are not adequately funded, equipped, regulated and managed to bring out their optimum potentials in youths and potential entrepreneurs.

4. Lack of Adequate Training: Absence of adequate training for students has made it difficult for them to propel transformation in the country. This challenges the future of the youth as entrepreneurs. Educational curriculum in Nigeria focuses more on the theoretical than the practical. Most employers are always compelled to retrain their employees due to lack of knowledge of basic work ideas or familiarity with the area of study of the employee. Technology has been used to improve the quality of life through the use of the computers and other technological discoveries such as the internet. Where the youth does not have the knowledge or skill of the latest technology, it affects their outlook to life. This also results in low morale, inefficiency and lack of confidence.

5. Lack of Access to Local and International Markets: The challenge of access to local and international markets stunt and retard entrepreneurial expansion because entrepreneurs find it difficult to successfully market and expand their business as a result of high cost of doing business. Enterprises can only succeed if awareness of market availability is created. 
6. Severe Infrastructure Deficits: Severe infrastructural deficits such as power and electricity that hamstring both new and existing businesses is also one of the challenges. In a report, the World Bank indicated that if government is able to remove power as a bottleneck, Nigeria will at least gain $30 \%$ competitiveness in production. It is therefore imperative that an effective energy policy be developed as business cannot thrive under a bad energy policy.

7. Inadequate access to finance and the absence of a viable credit policy that addresses the specific needs of enterprises also serve as a constraint.

8. Some of the he youths in most cases prefer businesses which will give them quick money to businesses such as agricultural ventures that take considerable time to mature to big profits.

\section{HOW TO BECOME SELF RELIANT AND MAKE YOUR OWN WEALTH}

This can help the youths to make their own wealth and stop depending on others for survival particularly the government.

Becoming self-reliant is one thing that might seem difficult to so many young people in Nigeria. What is involved in being self-reliant is just some level of confidence, hard-work and persistence in what you really know how to do. Being self-reliant means that you can be able to proffer solutions to your own immediate problems. When you are self-reliant you can cater for others with your resources, rather than relying on income from someone or government paid jobs. Sometimes it might be good to rely on people for help, at least it gives them a sense that they existed and gave you help, as at the time you really needed help, but a person must learn to pass through life's difficulties and trials in order to attain his/her maximum capacity.

Many great people you see today, were self-reliant because they thought of what they could do to change their world, that is why you see them in the position they are in now.

From the forgoing, the following are the basic tips to become self-reliant:

1. Think Broad of What You Can Possibly Do: For you to be a self-reliant person in Nigeria, you have to think wide in order to discover what you are passionate about. You have to think of something that you would always love to do anywhere and anytime. When you are able to think broad of what you can possibly do, it is just so easy to become a self-reliant person in Nigeria. It is a known fact that many unemployed youths in Nigeria does not think broad on what they can do for themselves to be self-reliant or independent rather they solely depend on the government for employment. Once you think broad and discover what you can do best, government may intervene through its youth employment policies to support you.

2. Have a Mindset that You Can Be Independent: Many Nigerians, especially the young people feel that they would have to attain a certain age and academic qualification before they can start fending for themselves, but that is a wrong perception. As a Nigerian youth, you have to be self-reliant by gaining entrepreneurial skills that will give you the mindset of being an independent person. If you also observe, in developed places, youths bring up innovative ideas and people would invest in it and in turn it would bring in profit for the youth as a reward, that is a clear situation of a youth being self-reliant. Having a mindset that you would have to depend on someone for help would likely make you not to succeed, because it would limit you from so many things. If you take a look at the Nigerian population, you would discover that you can become a successful person by bringing up ideas that can be profitable, which benefit the masses. 
3. Pursue Your Dreams: As a person who is hoping to be self-reliant in Nigeria, you have to do something that you love in order not to depend on people or the government for help. If you know how to sing, then sing well and be self-reliant, if you know how to dance, then dance well and be self-reliant, if you know how to write, then write well and be self-reliant and so on and so forth. It all depends on you. No man was born without talent. Discovering your talent and pursuing it at all cost can make you to become a selfreliant person. It might be tough learning how to be self-reliant, but you just have to pass through rough roads in order to discover your true potentials. Being self-reliant has to do with knowing your responsibilities and learning how to manage them by proffering the right solutions without external help.

4. Think of Alternative Sources of Income: A young Nigerian can be self-reliant by thinking of alternative ways to make money. Look at an example that illustrates this: You are a man and all you do is depend solely on your salary that the government pays you at the end of each month, let say government was not able to pay you for a particular month and you do not have any other source of income then does it mean you and your family would go hungry? Would you not pay the bills? But when you had already thought of alternative sources of income, you are automatically going to escape a bad situation by being self-reliant. Executing the plan, you had in mind of other ways to make money. There are several businesses you could do to boost your income that would not affect your normal job. All you have to do is create a little time for it and some investment that would not cost you much. Generally, what this point is trying to say is that thinking of alternative sources of income would surely make you to be self-reliant.

5. Understand Basic Things: If you really want to be a self-reliant person in Nigeria, then you would have to learn and understand basic things. You need to have a fair knowledge of many things that happen around you, even though you must have been specialized in one thing. Let us take a look at a situation where a man is an engineer and all he knows is about construction and the like, when he gets home, his wife cooks and he eat well but he does not know how to cook. But there is this weekend, where his wife travelled for a function and he was home and no food at home, does it mean that he would not eat the whole weekend, simply because he does not know how to cook? That shows he lacks "self-reliance". Your ability to do some certain things at some certain conditions makes you a self-reliant person. When you have basic understanding of things that happen within Nigeria, you can know what to do and how to do it without asking or relying on people for help.

\section{WHAT SHOULD THE YOUTHS DO IN AN ENVIROMENT WHERE GOVERNMENT JOBS ARE NOT READILY AWAILABLE?}

Crime is on the increase in Nigeria today because so many youths are jobless. Little is done to support Government efforts to engage the thoughts and energies of the youths. They have great potentials to create jobs for themselves and others, but cannot afford the cost of training. I believe, if given the opportunity, they will be resourceful to themselves and the country at large.

At this juncture, the youths are encouraged to engage themselves in specific trade areas such, bead making, shop making, hair dressing, computer training, tailoring, photography, videography, instrumentation, hair cutting, making of cosmetics, making of shoes, catering and confectioneries, interior and exterior decoration and learn some skills like welding, mechanic, building, panel beating among many others.

If Nigerian youths are to succeed, they must remain focused and stop over-reliance on the governments to pursue their dreams. Never wait for the government to do something for you. Its job is to create an enabling environment. Youth do not have to give up, you have to keep going. When you see your business is outdated, innovate. The youths should not pay attention to naysayers and instead focus more on putting their ideas to work. You will want to start a business and you will find people who will tell you that it will not 
succeed because there is so much competition, more money, more infrastructure, and more resources but that not derail you. There were many young and successful Africans who today are recognized and respected in America, Europe and the rest of the world, because they had succeeded exceptionally to become the best in a foreign country. The most important thing is to move from thinking, planning, preparing to implementing and do not get discouraged if you fail. Many people have had too many failures in life, they have made many mistakes and they always concentrate more on not repeating the same mistake. Mistakes will be made but you must move forward. Nigerian youths should seize opportunities to innovate and turn their challenges into profitable ventures. Young people have to be the driving force and take charge to build the future that Nigerians want. Work collectively and promote entrepreneurship, job creation for the better future of Nigeria. Work hard and you're your entrepreneurial dreams into working businesses.

Only a paradigm shift in the social consciousness of the literate youth can stem the surging tide of unemployment in Nigeria. Nigeria is a massive opportunity for innovative and enterprising young people to thrive. It is ironic that we have lots of unemployed graduates when there are lots of societal needs that are not being met in the Nigerian market. Entrepreneurs are created through education, experience and mentorship. Nobody is born with exceptional entrepreneurial insight, ability or skills. With the right skills and attitude, any Nigerian youth with ambition and ideas can go far because of the existing limitless opportunities in the market. Nigeria represents an exceptional and extremely exciting opportunity for young and smart entrepreneurs with guts. The Nigerian youths should get over the fixation for paid employment and to boldly venture into the uncharted informal sector.

\section{How Importance is Skill Acquisition for the Nigerian Youths?}

A skilled person can survive in any environment. As water is very essential to human life, so is skill training and acquisition needed in the life of every serious-minded human being. Skills can do a lot of great work in the life of every living soul. Lack of entrepreneurial skills is one of major the causes of unemployment and corruption. Youths are to gain skill in areas such as: Computer Literacy, Fashion and Designing, Cosmetology, Catering and Hotel Management, Bag/Shoe making, Hair Dressing, Bead-making and others.

The importance of entrepreneurial skill development in our society today cannot be over emphasized because gone are the days when jobs were available everywhere both in the private and public sectors of the economy and employers go about looking for potential graduates for employment. The question of choice of job or the type of employer one would like is now a story and thing of the old. White collar jobs are scarcely available. Hence many graduates are desperate to get any job to keep body and soul together. Indeed, there is paradigm shift in the labour market.

Therefore, the need to acquire and develop specific entrepreneurial skills cannot be neglected because entrepreneurship is vital to creating employment and indeed a special form of employability for graduates. Empowerment helps individuals or groups to fully access personal/collective power through knowledge, skills and motivation for proper functioning in their society and contribution to the economy. The importance of acquiring entrepreneurial skills includes:

(1). Self-employment: A self-employed person can never go hungry because the skill he acquired provides food for him/her on a daily basis. But one who lacks skill acquisition will find it difficult to be self-employed because he/she has nothing to offer.

(2). Helps the society not to depend on white collar jobs.

(3). Helps youth develop a positive attitude towards work and labour.

(4) It reduces poverty.

(5). Helps youth to be self-reliant and independent. 
(6) Diverse job opportunities.

Have you ever seen someone who acquires many skills alone? Such person is classified as someone who is up and doing. Those who have many skills stand the chance of gaining more jobs from many establishments. People who have many skills are being searched for by many companies. Company A, B \& C stand in a queue fighting over one person. They are searched for because they can do many functions due to the series of skills possessed.

Here are some of the major probably thousands of things to consider when deciding to become self-employed:

(1) Create goals you control: When working on a salary, goals change constantly and are out of individual direct control. While still having to meet the requests of customers, being self-employed can provide a more effective way of creating a more balanced lifestyle.

(2) Create agendas and plans that support your goals: Again, when working on a salary, the plans and agendas that are meant to meet the goals of the company change constantly. In a self-employed environment, plans and agendas that direct marketing, sales, production, and distribution can be developed and sustained with more consistency and effectiveness.

(3) Develop the resources, talents and skills that build and sustain a business: As a self-employed business person, developing the skills to negotiate contracts, manage employees and contractors, and manage time becomes even more important. In many ways, being self-employed is the most dynamic learning experience an individual will ever encounter.

(4) Stress can be reduced dramatically: Building a business that is suited to personal talents and skills creates an incentive to get up in the morning because it is something the individual enjoys doing. It can also give a sense of satisfaction and accomplishment at the end of the day. Added to this, a certain degree of financial comfort and stress can be reduced dramatically.

\section{CONCLUSION}

Today, we should know that entrepreneurship is promoted as an effective means of stimulating economic growth and development through the generation of greater employment opportunities for the youths. Lessons obtained from this paper will impart entrepreneurship skills and attitudes to the youths as well as dispose them towards establishing their own businesses. It will further reduce youth unemployment and empower them to contribute positively in the nation's economic development. It is hoped that the paper will educate the youths on the need for them to be self-reliant and self-employed that will make them to rise out of poverty and be self-employed and self-reliance. These youths would become skill vendors to train other unemployed youths. This would increase job opportunities and develop the economy of the nation. When the youths are engaged meaningfully in this way youth restiveness and crime would be reduced and people will live in peace and harmony.

However, rural youths in Nigeria have the potentials needed to participate effectively in agricultural development. Major problems encountered by youths in agriculture include lack of interest in agriculture as a result of drudgery in farm operations, lack of competitive market for agricultural products, lack of start-up capital, inadequate labour saving technologies for ease of operations, inadequate finance/credit facilities, among others. As a result, they are faced with serious economic challenges which result in undue poverty and vulnerability. This has also made youths to seek employment in other sectors of the economy in order to empower themselves economically, resulting in rural-urban migration and leaving the bulk of agricultural production in the hands of old people who often times produce at a subsistence level. These problems associated with unemployment can be solved by empowering the youths through agricultural development programmes which will enable them to have opportunities for self-employment in agriculture. There is therefore need for specific measures to be taken in order to address poverty among youths. The empowerment of 
youths through agricultural development programmes will reduce poverty and provide them with opportunities that will enable them to be gainfully employed. Governments at various levels are encouraged to promote youths in agriculture through creating awareness on Youth Employment in Agriculture Programme to enable young people to know about the programme and participate actively for enhanced agricultural productivity, increased food security as well as empowering them economically. Most rural youths do not foresee a prosperous future for themselves in the agriculture sector, mostly because of lack of profitability of agricultural activities and lack of physical and social infrastructure in rural areas. These infrastructures are necessary in order to reduce rural-urban migration and keep youths in rural areas as well as promote their interests in agriculture. Finally, dependent people often fail to find the motivation to solve problems on their own. Hence, self-reliance is vital for the Nigerian youth to successfully govern their own lives and economy.

Finally, In the face of the serious and growing threat of youth unemployment in Nigeria today, the need for the Nigerian youths of today to seek avenues for self-employment, self fulfilment and financial breakthrough is very crucial.

\section{RECOMMENDATIONS}

The paper recommends the following:

(1). Entrepreneurship should be taught as an activity (practical) and not just as an academic field or Entrepreneurship studies should be largely practical based to enable students acquire adequate skills and knowledge needed for self-employment.

(2). Appropriate conducive environment such as quality infrastructural facilities and start-up capacity should be provided to the youth by the government. In other words, Government should provide basic infrastructures such as regular power, good roads, communication etc for entrepreneurship to boost the Nigerian economy.

(3). There is the need for government to provide an enabling environment in the area of security as no meaningful entrepreneurial activity can take place in a volatile or crisis prone economy.

(4). It should be made compulsory for students of tertiary institutions to produce marketable products in their areas of entrepreneurial choice before graduation. This will enable them take entrepreneurship education very serious.

(5). There is also the need to place students on industrial attachment in relevant firms and industries for a specified period of time. This gesture will help solve the problem of theoretical learning of entrepreneurship education.

(6). Tertiary institutions require adequate funding by their sponsors. This will enable them acquire facilities for effective learning of entrepreneurship education.

(7). Staff training and retraining should be encouraged. This will enable trainees acquire modern skills as well as rich knowledge in the teaching of entrepreneurship studies, since one cannot give out what he does not have.

(8). The youths should be properly encouraged to become entrepreneurs through implementation of relevant policies, in order to forestall the problem of graduate unemployment in the country.

(9). Government should play a vital role in creating enabling environment to ensure that the youths who are in private business, are not unduly harassed by thugs hired by Government in the name of revenue generation.

(10). Tax holiday should be granted to youths who are engaged in micro businesses for a reasonable period of time. 
(11). Government should review and produce an appropriate youth development policy that outlines measures to reduce youth migration from rural to urban areas in order to sustain the agricultural human resources requirement and empower youths. In order to attract youths to agriculture, attitudes must change among rural communities to perceive it as a business and make it commercially viable.

(12). Efforts should be made to integrate the views of youths into developmental efforts in order to address the actual needs of the youths, thus making agricultural development planning and management sensitive to their needs.

(13). Rural youths should be involved in the drafting, implementation, monitoring and evaluation of policies and programmes related to agriculture.

(14). Education and capacity-building programmes for rural youths should be defined in a more participatory way and focused on agricultural best practices, land laws and knowledge sharing.

(15). Agriculture should be included as a compulsory subject in Nigerian schools starting from primary education curriculum in order to promote interest in farming among youths.

(16). Informal education programmes should also be implemented in rural areas to change the mind set parents have about agriculture.

(17). There should be regular seminars, workshops and conferences for staff, students and the general public to strengthen and refocus on entrepreneurial education. Strengthening research and capacity of researches into evidence-based researches will promote participatory methods. This will encourage synergy among government, private sectors and the general public on the need for encouraging and developing entrepreneurial spirits among students.

(18). Government should increase the budget for the implementation of government policy on mandatory entrepreneurship education and the budgeted sum should be released in order to actualize the purpose of the funding.

(19). Youths should be introduced to entrepreneurial activities at their early stage to enable them grow alongside with it in and out-ofschool programmes. Government should incorporate practical/field training scheme in the existing mandatory entrepreneurship curriculum of tertiary institutions.

(20). Entrepreneurship lectures, teachers/trainers should periodically be retrained and encouraged in the area of research to update their skills in order to be relevant in today's era of dynamic and globalized environment.

(21). Education curriculum must be immediately revised to incorporate skills and enterprise development. Hence a process or a program geared towards training youths in Nigeria in the act of entrepreneurship. They ought to be progressive, proactive and pragmatic.

(22). The government must be willingly to fund entrepreneurship activities since finance is one of the issues hindering entrepreneurship development in Nigeria.

(23). Nigerian government should strengthen the legal framework for entrepreneurship development programmmes, mandating states participation in the NDE and Amnesty programmes to ensure that strengths and potentials of the youths are geared towards economic developments rather than violence

(24). Government should create labour market that work better for the youths. 
(25). The youths should be encouraged to engage in the agricultural sector through various government's agricultural programmes and the government should provide incentives to those youths in the agricultural sector.

(26) The government should provide grants for innovative youths and those that are willing to be self-reliant as that will go a long way in motivating them and boosting their morale. As they become self-reliant and self-employed, it will reduce the burden and pressure on government (make the government less pressured).

(27). Above all, the youths should disabuse their minds from relying on the government for job creation. They should rise up and start doing something independently no matter how small it is, then the government may come in to support them.

\section{REFERENCES}

Audu, R., Yusri, B. K. \& Farhad, B. (2013). Technical Vocational Education: As a Veritable Tool

for Eradicating Youth

Unemployment. IOSR Journal of Humanities and Social Science

(IOSR-JHSS) 8(2): 10-17.

Ajani, E. N., Mgbenka, R. N. \& Onah, O. (2015). Empowerment of Youths in Rural Areas through

Agricultural Development Programmes: Implications for Poverty Reduction in Nigeria, International Journal of Research in Agriculture and Forestry, 2(2):34-41.

Idoma. K. \& Muhammad, I. (2013). Self-Reliance: Key to Sustainable Rural Development in

Nigeria. ARPN Journal of Science and Technology VOL. 3, NO. 6, June 2013.

Idris, Y. H., Asnarulkhadi, A. S., Ma'arof, B. R., \& Nobaya, A. (2016). Business Apprenticeship Training (BAT) and Youth Empowerment: A Strategy for Alleviating Poverty, Unemployment and Attainment of Self-Reliance in Nigeria. Newyork Science Journal, $\quad 9(12)$.

Mobilizing the Youth For Self-Reliance: An Assessment of Self-Help Initiatives Accessed \& Retrived from https://iproject.com.ng/political-science/mobilizing-the-youth-for-self- reliance-an-assessment-of-self-help-initiatives/index.html

Nnamani Emeka and Norbert Ile. (2013). Entrepreneurship Development and Unemployment in Nigeria. Asian Journal of Business Management Studies 4 (2): 22-29.

Nwaeze, C. \& Avoaja, P. C. (2017). An Appraisal of Entrepreneurship Education as a Key

to Employment Generation in Nigeria: A Case of Selected Tertiary Institutions in Abia State. The Macrotheme Review 6(2), Summer 2017.

Okoye-Nebo, C., Kenneth, I. \& Ugochukwu, U. (2014). Youth Unemployment and Entrepreneurship Development: Challenges and Prospects in Nigeria. Kuwait Chapter of Arabian Journal of Business and Management Review 4(4).

Shamsuddin, I. M., Adamu, T. A. \& Ibrahim, A. (2018). Entrepreneurship, Science and Technology Education for Self-Reliance and Economic Diversification. International Journal of Engineering Management, 2018, 2(1):1-7.

Tips To Become Self Reliant And Make Your Own Wealth Accessed and Retrieved from https://www.globalgiving.org/projects/empower-200-youths-in-nigeria/

Uddin, P. S. O. \& Uddin, O. O. (2013). Causes, Effects and Solutions to Youth Unemployment Problems in Nigeria. Journal of Emerging Trends in Economics and Management Sciences (JETEMS) 4(4):397-402. 
International Journal of Scientific and Research Publications, Volume 10, Issue 12, December 2020

ISSN 2250-3153

Uzoma, Aja \& Onele, A. (2013). Achieving Youth Empowerment Through Repositioning

Entrepreneurial Education

in

Nigerian Universities: Problems and Prospects. European $\quad$ Scientific Journal October 2013 edition Vol.9, No.28. 